AWEJ for translation \& Literary Studies volume, 1 Number 1, February 2017

Pp. 65-78

DOI: http://dx.doi.org/10.24093/awejtls/vol1no1.5

\title{
Pearl in Hawthorne's the Scarlet Letter: a Socio-Religious Perspective
}

\author{
Tatit Hariyanti \\ English Department, Faculty of Cultural Studies \\ Yogyakarta University of Technology, Yogyakarta, Indonesia \\ Dwi Nurhayati \\ English Department, Faculty of Cultural Studies \\ Yogyakarta University of Technology, Yogyakarta, Indonesia
}

\begin{abstract}
The relationship between literature and religion is still most often confined to the JudaeoChristian tradition, and it is used to recommend the analysis of the bible as literature and religious aspect of literary works. This paper aims at exploring the possibility that literature could be an alternative means to do comparative studies of certain religious aspects from different religion. It focuses on the name and the significance of the name of Pearl in Hawthorne's The Scarlet Letter which alludes to the Bible. This paper however will examine the name from different angle; that is from an Islamic point of view, for the purpose of a comparison. Pearl is also mentioned in Al-Qur'an and some Hadiths; therefore they will be the main sources to analyze the view on pearl. The result is that The Scarlet Letter shows the vivid image of Pearl in Islam. Pearls in Islam have both worldly and spiritual significance with their special characteristics such as being natural, beautiful, pure, invaluable and demanding great price and effort to gain them. Relating to the character of Pearl in The Scarlet Letter, Hawthorne depicts Pearl as having such characteristics .
\end{abstract}

Keywords: literature and religion, name of Pearl, socio-religious, The Scarlet Letter

Cite as: Hariyanti, T. \& Nurhayati, D. (2017). Fansubbing in the Arab World: Modus Operandi and Prospects. Arab World English Journal for Translation \& Literary Studies, 1(1). DOI: http://dx.doi.org/10.24093/awejtls/vol1no1.5 